\title{
A informação qualificada auxiliando na contínua formação dermatológica
}

\author{
Qualified information supporting continuous dermatology training
}

Se a informação médica pode - e deve - ser rápida, a formação profissional requer períodos de acúmulos fundamentais e está sempre exigindo ajustes e aprimoramentos. Com essa compreensão, referenciados em quais informações e em que base de formação nos iremos disponibilizar para a assistência aos nossos pacientes?

Os esforços devem ser direcionados para uma informação precisa e transparente, obtida a partir das melhores evidências; e para uma formação humanista, eticamente correta e sem concessões para os caminhos que não envolvam necessariamente estudo, trabalho, respeito e parcerias.

Dessa forma, o periódico Anais Brasileiros de Dermatologia pretende ser um instrumento informativo que possa servir à formação médica - e à dermatológica em especial. Determinado a cumprir sua missão de publicar o que há de importante em pesquisas e estudos na sua área de abrangência, reúne no presente número temas diversificados, que demonstram a multiplicidade e a riqueza da especialidade.

A doença de Kawasaki é o assunto da Educação Médica Continuada (Castro PA et al., páginas 317 à 331). É um tema com grande importância clínica, em face das possibilidades de complicações graves da doença. Salientamos aos leitores que uma boa leitura deste texto certamente reavivará suas lembranças teóricas e práticas dessa afecção, garantindo uma aprofundada atualização.

Presenteando nossa vocação histórica à observação, descrição e tratamento das dermatoses tropicais, abre-se no presente número um novo capítulo em nosso meio, diante da documentação da parasitose gnatostomíase, ocorrida em um paciente brasileiro que havia viajado ao Peru (Dani CMC et al., páginas 400 à 404).

Além da importante descrição desse caso clínico diferenciado, há de ser ressaltado um estudo original, em hanseníase, que procurou estabelecer a relação entre a presença de um polimorfismo genético (Val274Leu) e os títulos elevados de determinados anticorpos antifosfolipídios (o que poderia explicar, ao menos em parte, os fenômenos tromboembólicos nos pacientes com hanseníase) (Brochado MJF et al., páginas 335 à 342).

Recomenda-se atenção especial, também, para os artigos sobre concepções em relação às biópsias de pele e ao histórico e útil método de Tzanck, pois constituem oportunidades de leitura sobre assuntos da prática cotidiana, que se projetam para além da informação simples, oportunizando um exercício reflexivo interessante (Werner B, páginas, e Brito MMC et al., páginas 431 à 433, respectivamente).

Como comunicação aos leitores e sócios da Sociedade Brasileira de Dermatologia, ressalta-se que o sistema para a submissão on-line de artigos deve iniciar-se no bimestre julho-agosto de 2009 e que, também nesse período, as respostas aos questionários dos artigos da EMC (que geram pontuações à Educação Médica Continuada) já poderão ser enviadas on-line pelo site www.anaisdedermatologia.org.br. A partir do próximo número dos $\mathrm{ABD}$ (volume 84 , número 5), as respostas aos questionários serão aceitas exclusivamente on-line.

Esperamos que o número atual desta revista realmente seja útil.

Renan Rangel Bonamigo

Editor Científico Associado - Anais Brasileiros de Dermatologia

Como citar este artigo / How to cite this article: Bonamigo RR. A informação qualificada auxiliando na contínua formação dermatológica. An Bras Dermatol. 2009;84(4):315. 